\title{
SOB A LUZ DOS CANDEEIROS: MOVIMENTOS DO SAGRADO ${ }^{1}$
}

\author{
UNDER THE LIGHT OF LAMPS: SACRED MOVEMENTS
}

Arthur Seabra

Sou Arthur Seabra, fotógrafo documentarista, aluno do curso de Ciências Sociais da Universidade Federal da Bahia e secretário de comunicação do terreiro de candomblé Ilê Axé Ojisé Olodumare - Casa do Mensageiro, de nação Ketu, que está localizado na região rural de Barra de Pojuca, município de Camaçari, Bahia. Sou iniciado para Oxalá, Ogan confirmado para o orixá Exú, posições que muito me honram.

A obra ora apresentada consiste no registro de uma cerimônia de candomblé realizada em fevereiro de 2020. As imagens foram feitas com uma câmera DSLR Sony Alpha, equipada com uma lente fixa $50 \mathrm{~mm}$ de abertura máxima 1.4. Chama atenção a luz de candeeiros, que precisaram ser utilizados em virtude da falta de energia elétrica ocasionada pela queda de um poste na estrada que leva ao terreiro.

Um cenário ancestral foi assim recriado pelo "acaso", parecido com aqueles do século XIX e início do XX no Brasil, quando o povo preto em diáspora praticava o culto a orixá sob essas mesmas luzes, com os mesmos cânticos, danças e instrumentos musicais. Em uma noite, a fronteira da história foi transposta de maneira arrebatadora. Se concretizava ali algo que até então pairava apenas na nossa imaginação, quase uma ficção criada, mas que apresentava como um erro que o orixá Exú, o patrono do nosso terreiro, transformava em acerto para nos beneficiar com uma marcante experiência: tocar um candomblé à luz de candeeiros.

${ }^{1}$ Como citar: SEABRA, Arthur. Sob a luz dos candeeiros: movimentos do sagrado. Debates do NER, Porto Alegre, ano 21, n. 40, p. 485-494, 2021.

2 Graduando em Ciências Sociais pela Universidade Federal da Bahia. E-mail: arthur_seabra@yahoo.com.br. 
Algo que pode parecer de pouco significado ao grande público, para nós aqueles momentos adquiriram significados múltiplos: um "reviver" o que não vivemos, um "rememorar" pela memória dos nossos mais velhos, o praticar um sagrado onde sentir, ouvir, tocar era mais intenso e o ver se fez, e ainda se faz, por meio de imagens em tons amarelos dourados e negros, referendando a realeza africana da qual todos descendemos espiritualmente.

As cores, as formas, as luzes refletem algo de poesia, as sombras remontam ao não-lugar e também ao que não se pode revelar - o segredo; os corpos revelam sobremaneira o protagonismo dessa gente, seu compromisso com o sagrado e com o próximo. Essa junção de linguagens confere um lirismo que busca preencher de significado as imagens e se afastar tanto quanto possível das preconcepções e estigmas que pesam sobre o candomblé e que são fruto do racismo estrutural.

Para que essa celebração tivesse ocorrido, foi necessário força, superação, resistência, fé, alegria, amor, altruísmo, partilha, e tantos outros substantivos que são abstratos e estão no DNA do povo de candomblé, mas que cristalizam a prática, o cotidiano nas comunidades tradicionais de terreiros. Tudo isso subjaz neste conjunto de imagens. Resolvi dar o nome de movimentos do sagrado, exatamente porque é essa conjunção de fatores que alicerçam e são, ao mesmo tempo, a força motriz do candomblé. Isso é, sem dúvida, o que o faz sobreviver enquanto prática sagrada dotada de autonomia e liberdade.

A ausência de luz ou a escassez dela poderia ter sido um grande problema, entretanto foi isso que nos permitiu vislumbrar um candomblé de superação, que não poderia ser adiado. Calcado na força dos nossos ancestrais, no bojo de resistência para a perpetuação dessas práticas que ainda hoje mantemos, trazemos para perto de nós, por meio de cantos e danças, as divindades para confraternizarmos e reforçarmos nossa fé e esperança.

$\mathrm{O}$ que faltou de energia elétrica, sobrou em energia vital, o axe! Cantou-se, dançou-se, celebrou-se intensamente. Com pouca visão, outros sentidos afloraram-se para honrar o sagrado. Nossos ancestrais estavam todos ali presentes nos guiando na pouca luz, e haveria de ser assim até a última cantiga da cerimônia que, como por mágica, trouxe a luz elétrica. Nesse 
momento entendemos que aquela cerimônia deveria ter ocorrido da forma que foi, sob a luz de candeeiros. Entre o movimento da chama dos lampióes e o nosso movimento, o sagrado se fez presente.

Foto $1^{3}$ - Atabaque ou ilú são instrumentos feitos em madeira e couro animal que, sacralizados, fazem a comunicação entre os humanos e as divindades. Através deles são executados os ritmos específicos a cada orixá.

Os atabaques recebem oferendas, têm nomes específicos de acordo com seu tamanho e com o som que emitem, e só podem ser tocados por quem passou pelos processos iniciáticos. Os ogans - homens que não incorporam suas divindades - são os responsáveis pela conduçáo rítmica e pela boa conservação dos instrumentos. É o toque do atabaque e demais instrumentos litúrgicos (agogô, xequerê) que marcam o início de cada festa pública de candomblé.

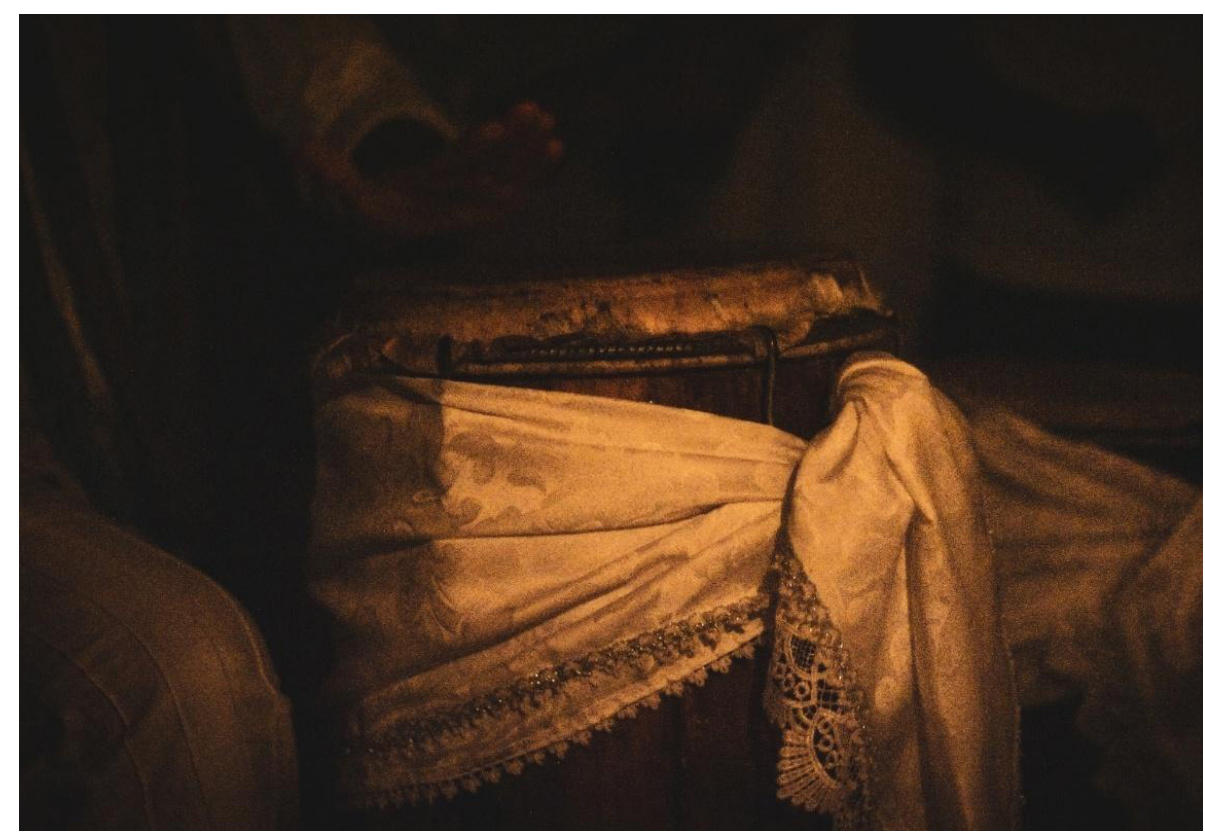

${ }^{3}$ Créditos das fotos: acervo do autor, 2020.

Debates do NER, Porto Alegre, ANo 2I, N. 4O, P. 485-496, Ago./Dez. 202 I 
Foto 2 - No Ilê Axé Ojisé Olodumare há uma espécie de antessala onde se forma a fila para adentrar ao barracão, no qual será feita a roda para a celebração principal, o xirê - a sequência de cantigas para os orixás. Nesse lugar é organizada a ordem de entrada de acordo com a posição hierárquica que cada pessoa ocupa no terreiro, começando com o babalorixá e indo até o yaô mais novo. Na fotografia, uma yầ com pouco tempo de iniciada senta por um momento à espera de tomar seu lugar na fila para entrar no barracão e compor a roda.

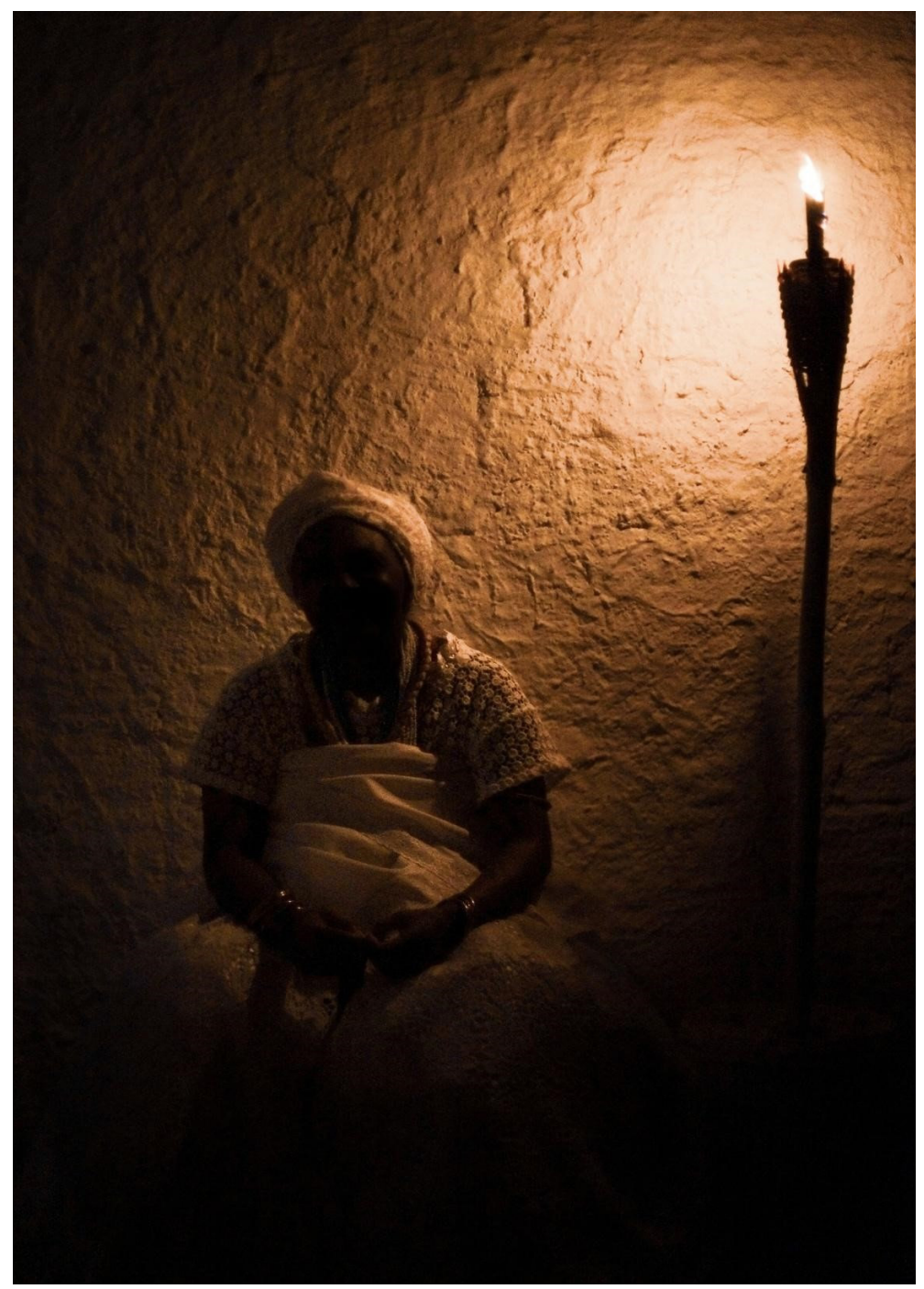

Debates do NER, Porto Alegre, ano 2I, N. 4O, P. 485-496, AGo./DeZ. 202 I 
Foto 3 - Iniciada que estava recolhida há vários dias no roncó, o quarto sagrado onde os iniciados ficam recolhidos para passarem pelos ritos necessários, quer seja na iniciação, ao completar 3 anos e 7 anos de iniciação. Esse dia marca um momento de amadurecimento na vida de axé da iniciada. No momento da foto, ela entra no barracáo ao som da avamunha, um ritmo que marca o início das celebraçóes na Casa do Mensageiro.

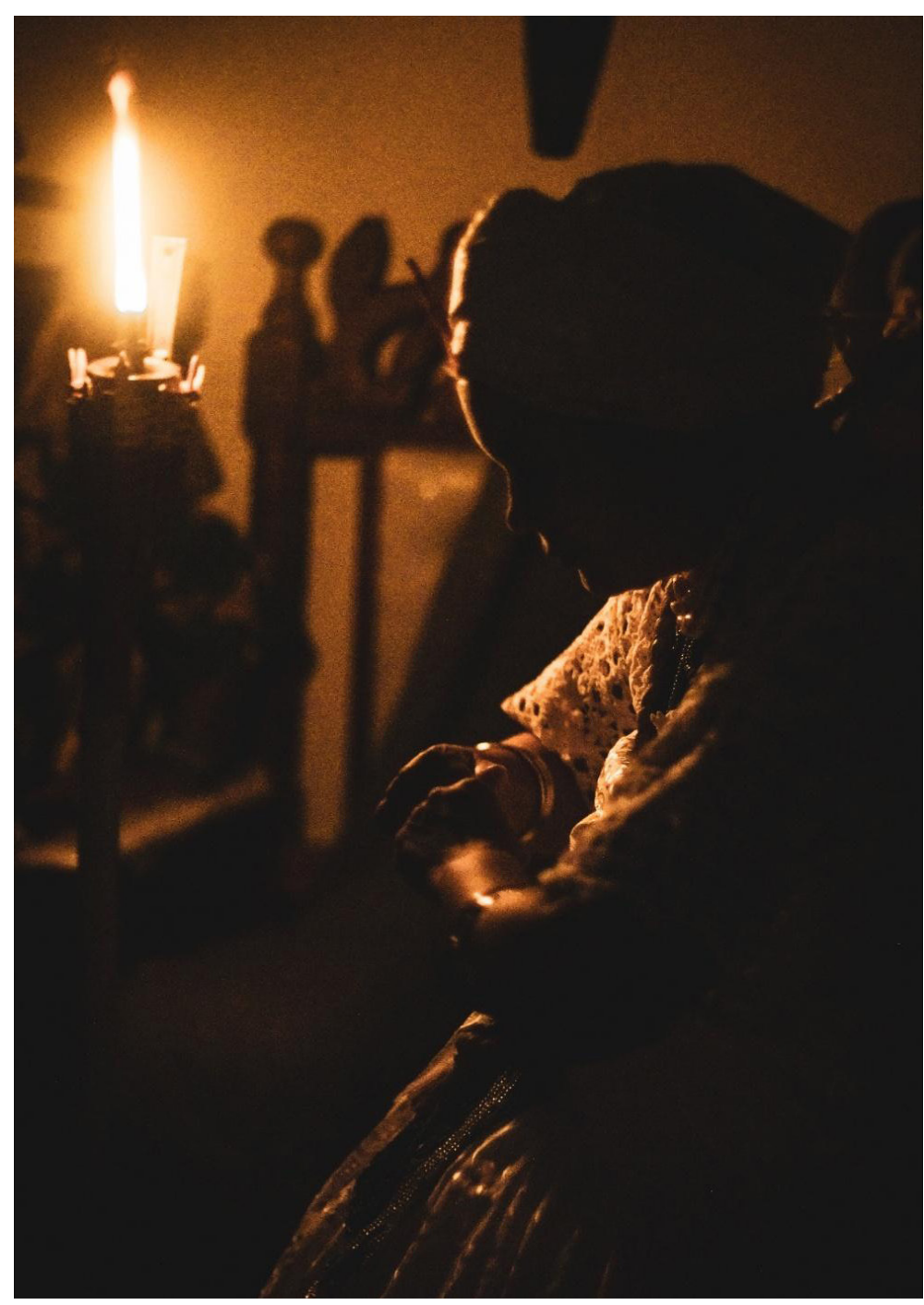

Debates do NER, Porto Alegre, ANo 2I, N. 4O, P. 48 5-496, AGo./Dez. 202 I 
Foto 4 - Yaôs se preparando para saudar a porta da rua. Essa é uma parte fundamental das celebraçôes, logo após o início das cerimônias de candomblé. Todos devem saudar a porta da rua do barracão, entre outros pontos sagrados dentro do terreiro.

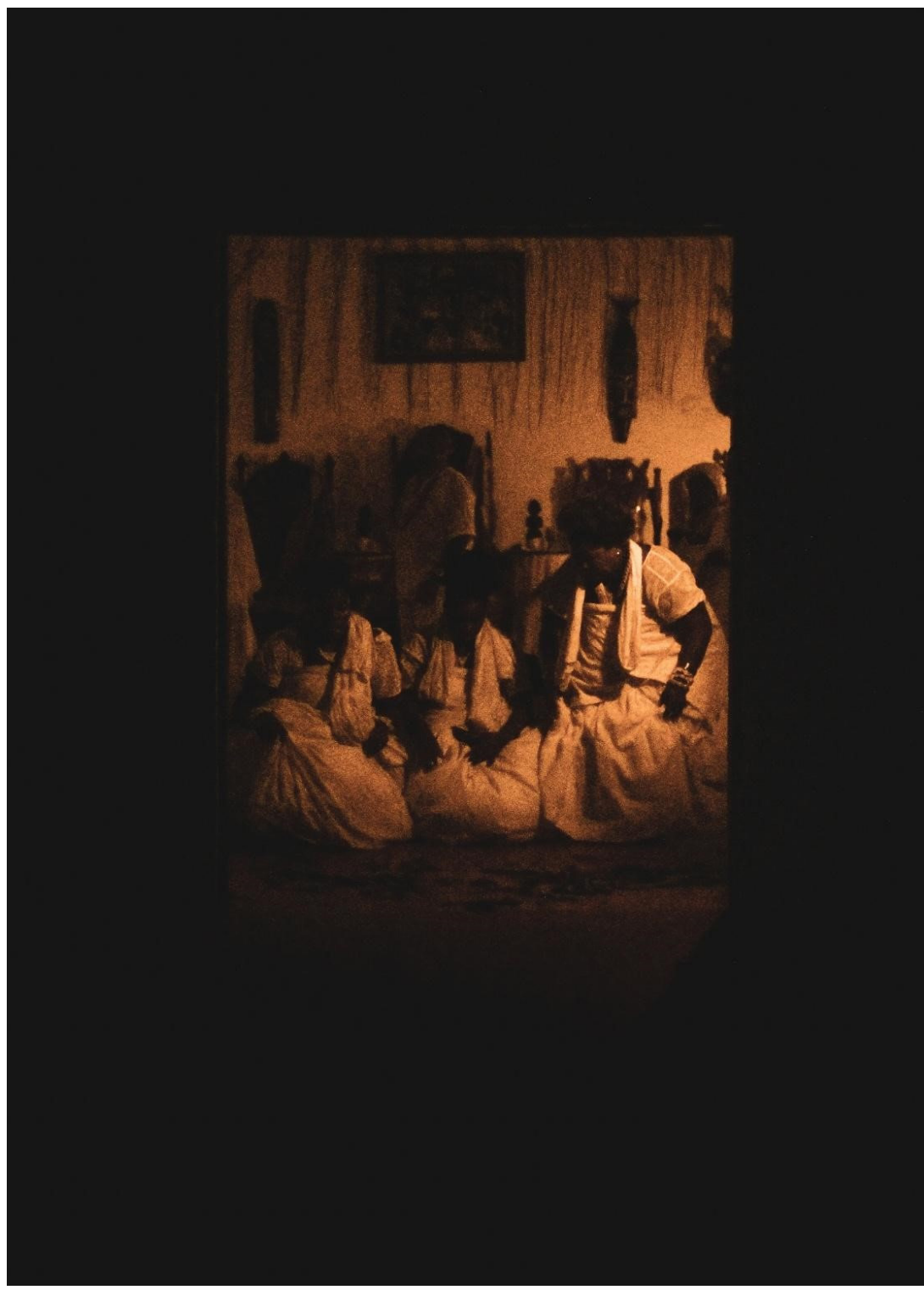

Debates do NER, Porto Alegre, ano 2I, N. 4O, P. 485-496, Ago./Dez. 202 I 
Foto 5 - A saudação consiste em prostrar-se e encostar a região frontal da cabeça descoberta no solo, reverenciando a porta como a representação do caminho que nos conduziu até aquele lugar sagrado - o terreiro -, e ao mesmo tempo pedindo caminhos de sucesso. A porta da rua é também o lugar onde é assentado um Exú a quem pedimos proteção e a "abertura" dos nossos caminhos. A saudação é feita sempre na ordem da roda, respeitando a hierarquia e o tempo de iniciação de cada pessoa. Isso tudo precisa ser feito com certa agilidade para a roda não parar por muito tempo, pois a mesma conduz uma energia dinâmica que deve fluir constantemente.

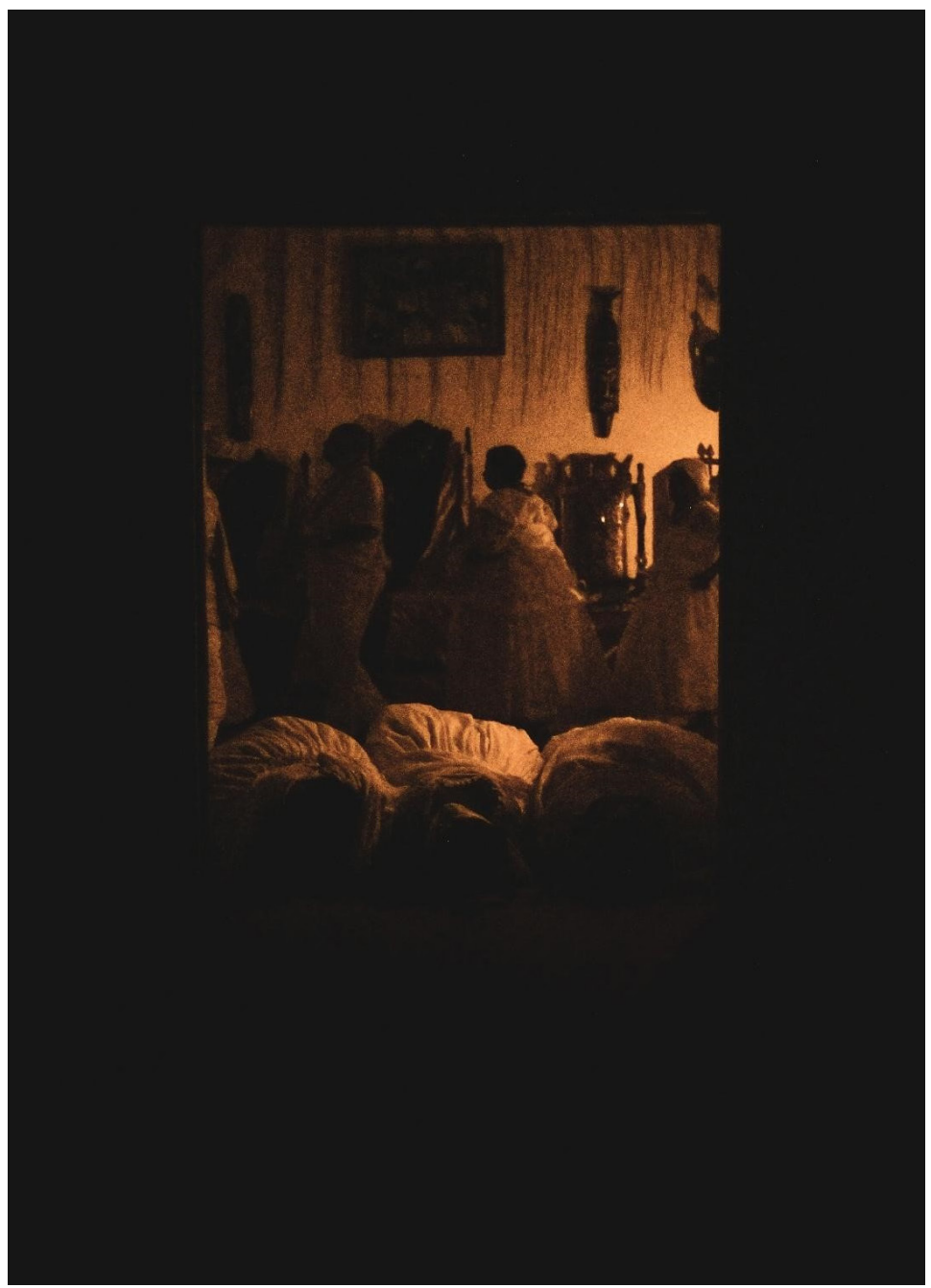

Debates do NER, Porto Alegre, ano 2 I, N. 40, P. 485-496, Ago./DeZ. 202 I 
Foto 6 - Yầ indo saudar o babalorixá no momento em que são entoadas cantigas para o orixá ao qual foi iniciado. Isso também faz parte da liturgia do candomblé. É uma regra primordial, cada vez que se começa a sequência de cantigas para o orixá ao qual se é consagrado, o filho-de-santo deve se dirigir às pessoas com as quais têm vínculos iniciáticos para pedir-lhes a bênção como um gesto de reverência, respeito e gratidão.

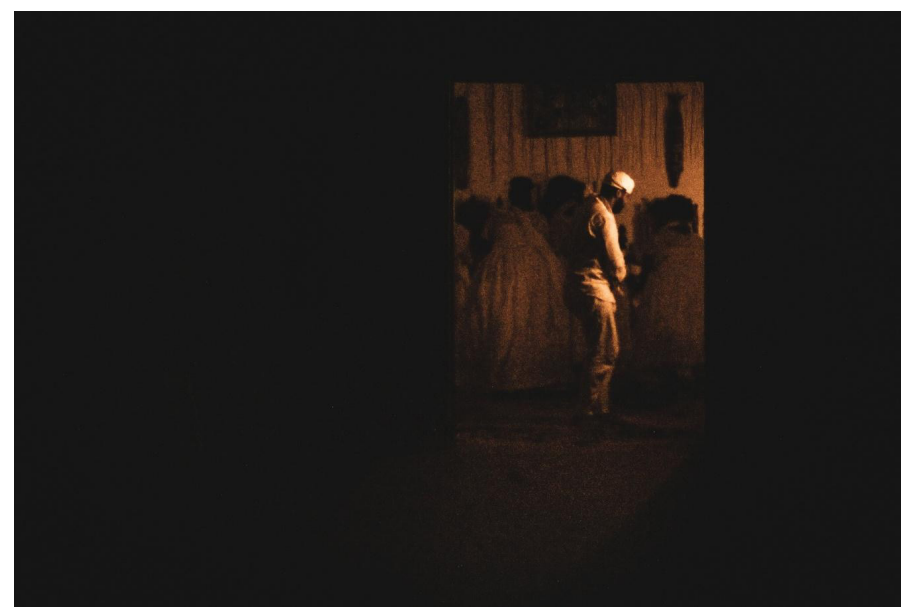

Foto 7 - Ekedes observando o andamento dos trabalhos durante a cerimônia, prestes a atender alguma necessidade de ordem litúrgica vinda das divindades manifestadas, dos membros do terreiro ou dos visitantes. Pelo fato de ficarem conscientes durante a celebração, elas têm autonomia e autoridade dadas pelos orixás para atenderem tais demandas.

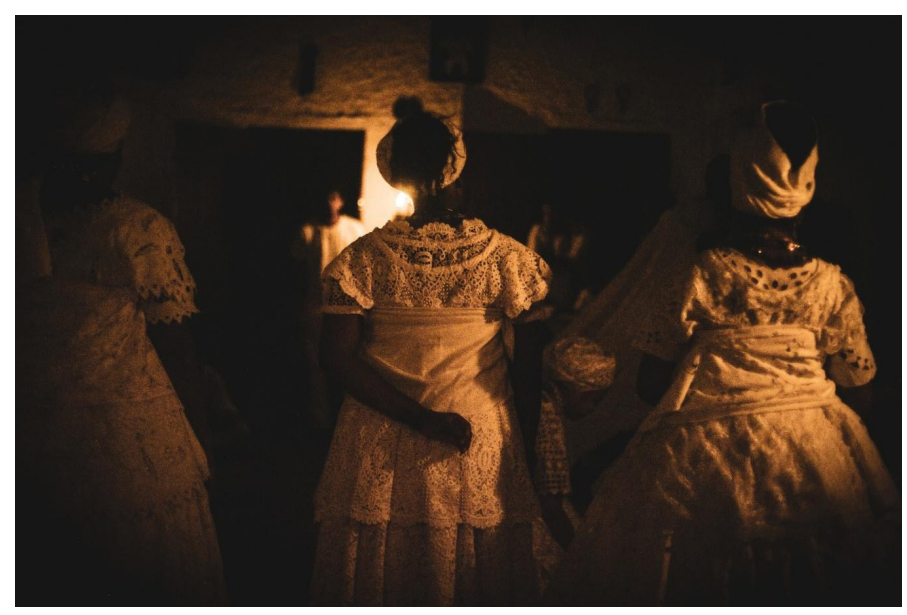

Debates do NER, Porto Alegre, ano 2I, N. 40, P. 485-496, AGo./Dez. 202 I 
Foto 8 - Yatebexé é o cargo destinado à pessoa do sexo feminino, que, por ser profunda conhecedora das cantigas, é responsável por cantar durante a celebraçáo. Ela é quem sabe em que momento qual cantiga deve ser entoada para cada orixá, fazendo, assim, com que a festa siga um fluxo orgânico e alegre.

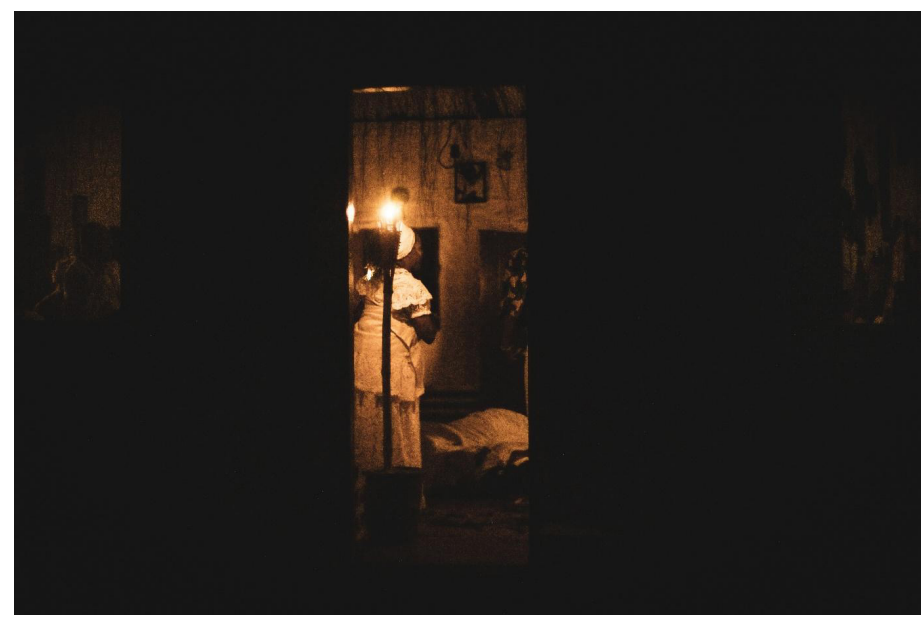

Foto 9 - O branco das vestes absorve os tons amarelados da luz do fogo e as sombras complementam o cenário ancestral. Na cadência de ritmos e cantigas entoadas com muito entusiasmo, pouco se viam as faces das pessoas, a atmosfera era de absoluta conjunção das forças vitais, entre o Orun (o céu) e o Ayê (a terra).

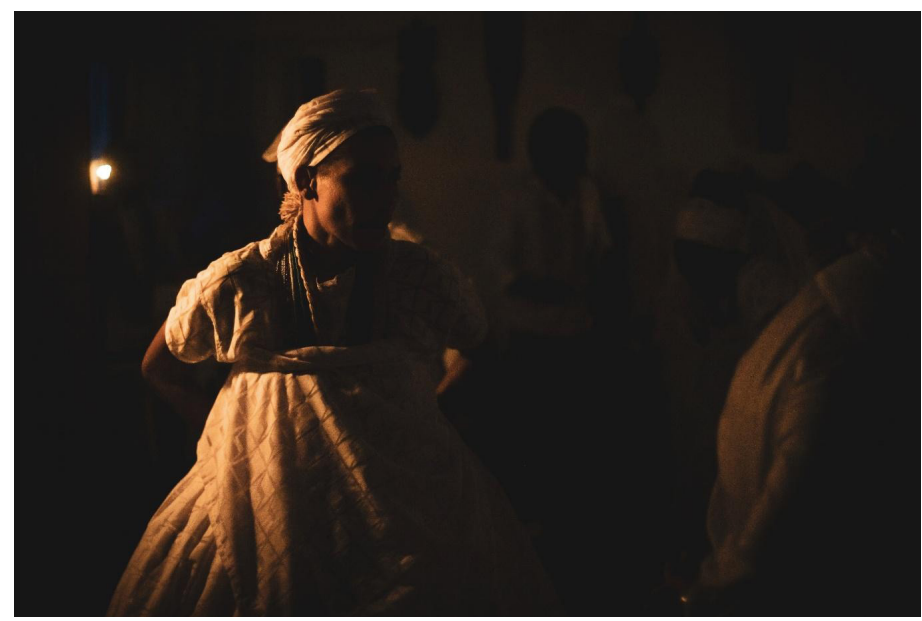

Debates do NER, Porto Alegre, ANo 2I, N. 40, P. 48 5-496, Ago./Dez. 202 I 
Foto 10 - Ao final, a culminância se faz cantando para Oxalá, que na tradição do candomblé nagô é o orixá mais velho, o responsável pela criação dos homens, o sábio, que é lento, que traz a paz e a quem todos devemos reverenciar. Todos os outros orixás se apresentam em seus filhos para confraternizar com o grande Pai e com os presentes. $\mathrm{O}$ ritmo lento das cantigas propicia um clima de leveza e paz. Aos poucos, a roda se transforma em uma fila se dirigindo ao interior do terreiro, esvaziando-se assim o barracáo principal, que conta ainda com a presença do público para o ajeum, que é o momento sagrado de congraçamento e partilha entre todos, da comida que foi feita com muito amor ao longo do dia.

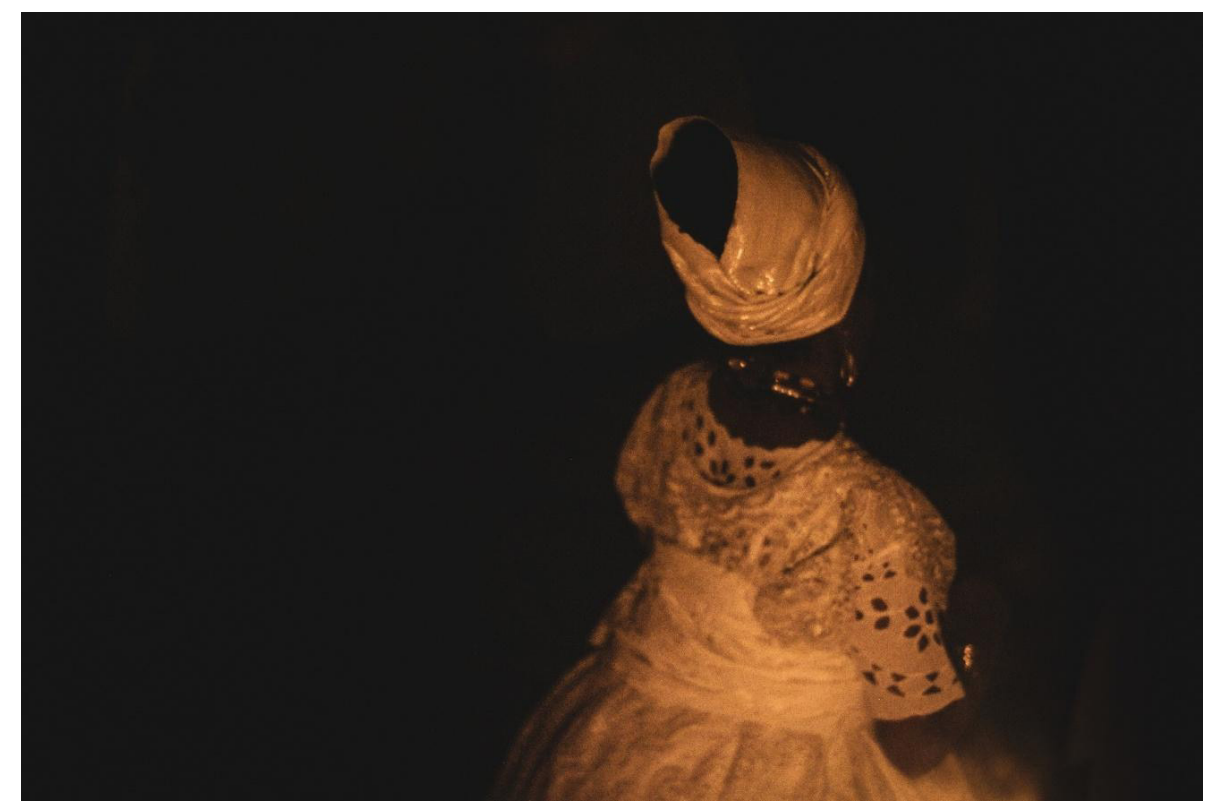

Recebido em: 15/07/2021

Aprovado em: 15/07/2021 

RESENHA 